\title{
Global brand market-entry strategy to manage corporate reputation
}

Article in Journal of Product \& Brand Management · May 2009

DOI: $10.1108 / 10610420910957807$

CITATIONS

29

3 authors:

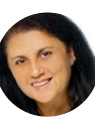

Maktoba Omar

Coventry University

57 PUBLICATIONS 229 CITATIONS

SEE PROFILE

David C. Lingelbach

University of Baltimore

20 PUBLICATIONS 96 CITATIONS

SEE PROFILE

Some of the authors of this publication are also working on these related projects:

Project

Gastrogatherings.com View project

Project

Vintage Marketing Differentiation; new book by Palgrave View project
Robert Williams, Jr.

Susquehanna University

32 PUBLICATIONS 132 CITATIONS

SEE PROFILE

All content following this page was uploaded by Robert Williams, Jr. on 07 January 2015.

The user has requested enhancement of the downloaded file. All in-text references underlined in blue are added to the original document and are linked to publications on ResearchGate, letting you access and read them immediately. 


\title{
Global brand market-entry strategy to manage corporate reputation
}

\author{
Maktoba Omar \\ School of Marketing and Tourism, Napier University, Edinburgh, UK, and \\ Robert L. Williams $\mathcal{F r}$ and David Lingelbach \\ School of Business and Leadership, Stevenson University, Owings Mills, Maryland, USA
}

\begin{abstract}
Purpose - This paper aims to present a case for the practical management of corporate reputation, in relation to two groups of concepts: communication, identity, and trust; and communication, identity, and image.

Design/methodology/approach - A review of the current knowledge of corporate reputation, personality, identity, and image leads to development of a strategy framework to enhance/protect corporate reputation. A case study involving a corporate logo introduced into a developed market by an emerging multinational corporation (EMNC) is presented.

Findings - The paper identifies that credibility and trust are significant elements which must be managed and communicated to maintain the firm's corporate image and reputation.

Originality/value - A conceptual model is presented illustrating a series of internal and external factors affecting communication and trust, which influence the customer and assist in shaping corporate reputation. The case of the EMNC Chinese corporation Haier to introduce its brand into a developed market may enlighten others pursuing this path.
\end{abstract}

Keywords Brand image, Multinational companies, Trust, Communication

Paper type Research paper

An executive summary for managers and executive readers can be found at the end of this article.

\section{Introduction}

The resource-based view within the strategy literature has argued that sustainable competitive advantage is created primarily from intangible capabilities, notably innovation, organisational architecture, strategic assets, and reputation (Kay, 1995). These capabilities serve as the foundations for the direct sources of competitive advantage: cost advantages arising from privileged access to critical assets and proprietary technology; customer captivity via habit formation, high switching costs, and high substitute search costs; economies of scale; and other factors, such as government protection or superior access to information (Greenwald and Kahn, 2005). Of those capabilities underlying competitive advantage, reputation plays a central role in certain types of consumer buying decisions. These decisions involve products that cannot be inspected in advance or are only consumed once. Pension plans, funeral services, and, more prosaically, consumer durables (such as cars or washing machines) are examples of such buying decisions (Kay, 1995). However, the creation of reputation depends on a firm's organisational architecture, which also plays a central role in creating and maintaining innovation. While reputation is a difficult concept

The current issue and full text archive of this journal is available at www.emeraldinsight.com/1061-0421.htm

Journal of Product \& Brand Management

18/3 (2009) $177-187$

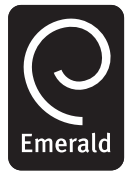

(C) Emerald Group Publishing Limited [ISSN 1061-0421]

[DOI 10.1108/10610420910957807] to measure, managers frequently assume a positive relationship between business performance and corporate reputation. The literature avers that from a customer's perspective, a healthy reputation may act as a risk suppressor, (Fombrun and Rindova, 1998). Early research on corporate reputation started with corporate image, corporate identity, and personality. Between the 1950s and the 1970s the focus was primarily on the image that external stakeholders held of a firm or store (Caruana and Chircop, 2000; Martineau, 1958). During the 1970 s and early 1980 s strategy moved to centre stage and corporate identity and corporate personality become salient. The focus has shifted to corporate reputation in the late 1980s (e.g. Fombrun and Shanley, 1990).

Corporate reputation has been gaining notice in the last few years as an important asset of the firm (Black and Carnes, 2000). Academicians in corporate strategies have begun to recognise the fact that corporate reputation provides firms with competitive advantages (Fombrun, 1996). The better the organisation's quality, the more it will become popular with its customers to continue using similar services of the organisation for projects related to its experiences (Hebson, 1989; Connor et al., 1997). In many cases, prospective customers are less inclined to work with new organisations with no track record, particularly for large-scale projects, because they fear negative consequences that may have an adverse effect on their businesses (Hebson, 1989).

The objective of this paper is to review the literature in relation to corporate reputation, its importance, and its relation to other concepts; display a framework and measurement approach; and finish with recommendations and research agenda. This paper will use Haier Corporation as a case study. 


\section{Corporate reputation}

Corporate reputation is seen as the outcome of a competitive process in which firms signal their essential characteristics to constituents to maximise social status (Spence, 1974). The cumulative value judgements by the public over time provides the company with significant competitive advantages (Fombrun and Shanley, 1990; Balmer, 1998; Fombrun and Van Riel, 1997). The definitions of corporate reputation have considered four main elements. Object specific components (Brown, 1995; Levitt, 1965) are based on the facts that the firm is well known: good or bad. Net effective or emotional reactions (Fombrun, 1996) based on the overall estimation in which a firm is held by its constituents. Past actions (Weigelt and Camerer, 1988) where corporate reputation is defined as a set of economic and non-economic attributes ascribed to a firm and inferred from the firm's past behaviour. Information cues result from direct and indirect experiences and information received (Fombrun and Shanley, 1990).

Herbig and Milewicz (1995, p. 24) define reputation as "the estimation of the consistency over time of an attribute of an entity. This estimation is based on the entity's willingness and ability to perform an activity repeatedly in a similar fashion. An attribute is some specific part of the entity-price, quality, and marketing skills”. Fombrun (1996) defines corporate reputation as the net perceptions of an organisation's ability to meet the expectation of all its stakeholders. In general, the reputation of a firm is perceived as the strong relationship between the customers and the organisation, which is viewed as client relationship-building. That is considered being an important element that contributes to successful organisation (Crosby et al., 1990; Hebson, 1989; Howard, 1998; Connor et al., 1997; Dollinger et al., 1997).

\section{Why is corporate reputation important?}

An empirical study by Fombrun and Rindova (1998) with leading US/UK companies found that those companies with a more positive reputation appeared to project their core mission and identity in a more systematic and consistent fashion than companies with lower reputation rankings. Further, these companies try to impart significantly more information, not only about their products, but also about a range of issues relating to their operations, identity, and history. Satisfactory corporate reputation is an important driver of successful organisational relationships with clients, which can have a significant impact on the business performance of an organisation (Ewing et al., 1999). Academicians agreed that corporate reputation is an important asset for the firm, it generates goodwill to the firm and it must be constantly maintained, as it is very fragile and extremely hard to repair (Black and Carnes, 2000; Howard, 1998).

An exceptional reputation will distinguish the firm from its competitors (Howard, 1998). In addition, it will lead the customer to assume that the products have a higher quality (Dowling, 1994; Greyser, 1995), and may enable the firm to command premium price (Klein and Leffler, 1981), attract better applicants and investors (Stigler, 1962; Milgrom and Roberts, 1986), enhance the organisation's access to capital markets (Beatty and Ritter, 1986), and to
Volume $18 \cdot$ Number $3 \cdot 2009 \cdot 177-187$

generate word-of-mouth endorsement and act as a barrier against imitation (Fombrun and Gardberg, 2000).

\section{Enhance corporate reputation}

"Companies should focus on managing their corporate brand as a means of manageing their corporate reputation" (Argenti and Druckenmiller, 2004, p. 374). Fombrun (1996) illustrates that managers should pay an increased attention to building and sustaining their reputation for great economic returns. This can be achieved by the following practices: shape a unique identity, and project a coherent and consistent set of images to the public. The organisation's reputation derives from its unique product offering. In turn the uniqueness of the product offering calls for management practices that stress product quality and customer service. The above two points can include: design a programme that keeps the customer happy through good quality products and services; keep the employees informed of the reputational side effects; show sensitivity to the environment; hire PR staff to safeguard communications through the media; and work on community involvement.

Our understanding of the complex phenomena surrounding advancing and enhancing corporate reputation is of particular pertinence. These conditional generalisations (as social scientists would call them) about the variations are what drive corporate reputation in different countries, industries, and strategic situations. Other than highly visible company crisis-type situations, one rarely reads about only modest deterioration of corporate reputations. While we need to learn more about building reputation, we also need to learn about rebuilding it (if company behaviour permits).

\section{Reputation in relation to corporate personality, identity, and image}

Although the focus of this paper is to investigate the management of corporate reputation, it is necessary in advance to discuses its relationship with other related elements such as corporate personality, corporate identity and the corporate image. The success of a companies' reputation depends on how it develops a unique set of skills and a unique identity. The literature tends to create misunderstanding between the concepts of corporate reputation, identity and image (Van Riel, 1995). These concepts frequently appear in the literature as identical, as totally separate concepts or as interrelated phenomena depending on the viewpoints adapted (Gotsi and Wilson, 2001). This section will investigate the variables that have influence on/or are affected by corporate reputation, i.e. corporate personality, corporate identity, and corporate image.

\section{Corporate personality}

As result of the absence of a general definition of corporate personality, companies may encounter problems in their development or identification process. As already suggested by Abratt (1989) corporate personality is closely integrated with corporate identity. Abratt established that a firm's identity is developed and based around what is central, distinctive and enduring about the firm's character. This results in the corporate identity becoming a reflection of the personality and core beliefs of an organisation. Every 
organisation is unique, and the identity must spring from the organisation's own roots, its personality, its strengths and its weaknesses (Olins, 1989). Thus, corporate personality is the initial building block to each of the other elements. According to Olins (1989) it is common for organisational personalities to originate from the personality of the firms founder, however, they may also be derived from the organisational culture, core beliefs and values (Fill, 1999). Markwick and Fill (1997) suggested that the corporate personality is comprised of two distinct elements; the culture of the organisation, and the organisation's overall strategic purpose. Bromley (2001) defined corporate personality as what the organisation really is.

From these definitions, it is evident that there is an element of ambiguity surrounding corporate personality and its definition. Despite numerous academics acknowledging its significance in the creation of a corporate identity, Abratt (1989) suggests that the corporate personality is vital to the development of a corporate identity and thus the corporate image (see Figure 1). The majority of past authors have determined that the corporate identity and the corporate personality are distinct from each other yet highly interrelated. The corporate identity is developed from the corporate personality and the core values of the organisation and is then projected to the firm's publics in order to develop a corporate image. This notion is expressed by Olins (1989), who stated that "a good corporate identity is one that will identify and express the personality of the corporation, and that the corporate identity is" the tangible manifestation of a corporate personality. It is the identity that projects and reflects the reality of the corporate personality.

\section{Corporate identity}

There appears no generally agreed upon definition of corporate identity (Christensen and Askegaard, 2001; Balmer, 1995; Abratt, 1989; Ind, 1998; Olins, 1989; Christensen and Askegaard (2001) explain this ambiguity by claiming that "much literature dealing with these notions (corporate image and corporate identity) is written at a superficial theoretical level" and as such are not fully applicable or relevant to the organisation. Van Riel (1997) indicate that defining the corporate identity can be problematic. Alternatively, they produce what is known as the Strathclyde Statement, which is that every organisation has an identity, which articulates the corporate aims and values and presents a sense of individuality that can help to differentiate the organisation within its competitive environment. Despite the fact that there is a lack of agreed upon definitions, a number of definitions have been proposed. Balmer and Stotvig (1997) define corporate identity as the strategically planned and operationally applied internal and external self-presentation and behaviour of a firm. It is based on an agreed firm philosophy, long-term firm goals, and a particular desired image, combined with the will to utilise all instruments of the firm as one unit, both internally and

Figure $1 \mathrm{~A}$ new approach to the corporate image management process

\begin{tabular}{|c|c|c|}
\hline Corporate & Corporate & Corporate \\
\hline Personality & Identity & Image \\
\hline
\end{tabular}

Source: Abratt (1989) externally. He also describes corporate identity as the combination of visual and non-visual means a firm chooses to identify itself to all its relevant target groups.

Hannebohn and Blöcker (1983) state that corporate identity is the strategy that helps to increase the economic performance and the efficiency of a firm. Corporate identity co-ordinates achievements, values and information, and leads to integration in the sense of co-operation. Albert and Whetten (1985) point out corporate identity is comprised of the visual cues that the public use to recognise a firm and differentiate it from its competitors. Bromley (2001) debates that corporate identity is the set of attributes that help in distinguishing one firm from another. Others believe that the corporate identity becomes particularly significant in differentiating similar companies with similar offerings (Albert and Whetten, 1985; Balmer, 1995). Fill (1999) defines corporate identity as being the way in which the organisation presents itself to its stakeholders. However, Markwick and Fill (1997), see the corporate identity as "representing how the firm would like to be perceived, introducing itself to different stakeholders, and distinguishing itself from other organisations."

Olins (1989) details his opinion on the existence of a "design-approach" to the corporate identity. In this school of thought, it is suggested that designs (i.e. corporate logos and letterheads) are "virtually the sole vehicle" of the corporate identity. This superficial element to the corporate identity can also be found in the "Design-as-fashion" school of thought as suggested by Balmer (1995). In addition to this design-asfashion school of thought Balmer highlights the existence of a further six schools of thought:

1 Strategic.

2 Strategic visual.

3 Behavioural.

4 Visual behavioural.

5 Total corporate communications.

6 Visual communications.

It has been widely agreed that in order for the corporate identity to be successfully projected and sustain a positive corporate image it should remain consistent at all times and be based upon reality (Balmer, 1995).

\section{Corporate image}

Academics and practitioners dealt with the chronological development of the corporate image since 1950s (e.g. Abratt, 1989; Gotsi and Wilson, 2001). Most of the literature attempted to investigate the differences, linkages and similarities between corporate identity and corporate image. Although the concepts of corporate image and identity are certainly separate from one another, they are also highly interrelated (Christensen and Askegaard, 2001). Olins (1989, p. 212) provides a simple description of corporate image as being "what people actually perceive of a corporate personality or a corporate identity". However, he does acknowledge that his definition may be superseded in future studies or with the development of the business environment.

There is a relatively general consensus that although these definitions do convey the notion of corporate image, they are not sufficiently detailed. Simplistic definitions exist of the corporate image such as that of Balmer (1995), who defines it as "commonly held perceptions of an organisation by a group or groups". Fill (1999, p. 567) adds another factor to his 
definition of corporate image by including the notion of stakeholders' interpretation of identity cues, in order to form an image of the organisation. He defines corporate image as being "the perception that different audiences have of an organisation which results from the audiences' interpretation of the cues presented by an organisation". Christensen and Askegaard (2001) also tender a basic classification, regarding the corporate image as merely "the reception of an organisation in its surroundings." From the similarity of these definitions provided above, it can be determined that the corporate image exists externally to the organisation in the perceptions of firm stakeholders. Because of this, a firm cannot directly manage their corporate image but instead must focus on the corporate identity that they project (Abratt, 1989; Christensen and Askegaard, 2001; Fill, 1999; Markwick and Fill, 1997). Balmer and Stotvig (1997) suggest that the corporate image is a direct projection of the corporate identity. This however does not take into account influencing factors that are external to the organisation, such as different stakeholders may form different perceptions of the same organisation or that a halo effect exists (Fill, 1999). The halo effect should be recognised as when "a judgement of any organisation is based upon a striking characteristic. Haloes can be positive or negative" (Buchanan and Badham, 2001).

\section{Framework}

A framework is developed within which a strategy to enhance or protect corporate reputation may be understood and planned. It sees such strategy as on the one hand inextricably linked to effective corporate communication and on the other hand to the building of public trust.

\section{Communication}

Firms should consider the importance of communication internally and externally. This implies that the firm has complete control over all aspects of communication used to communicate with their publics. The finding of Fombrun (1998) indicated that in addition to the benefit the firm can gain from the frequency of communication, there is the different issues the firm reveals through its communication. For example, stakeholders will appreciate the transparency of a firm as it gives them a sense of greater reliability. Identifying the interfaces, Abratt (1989) defines the identity/image interface as the crucial point of contact between the firm and its various stakeholders. This viewpoint was developed by Rindova's (1997) model of the image and reputation formation process, which defines projected images as the collective output of communications from the firm to its stakeholders. Lewis (2001) stresses the importance of developing a dialogue, by knowing what matters to an audience and communicating on that level, rather than a monologue designed to deliver a message.

There is nothing better and more powerful than an organisation that understands itself, knows its aims and goals, has dedicated, committed and enthusiastic employees, and that relishes two-way communications with its key audiences (Howard, 1998). It is through the medium of culturally influenced interpretations of organisation images held by its publics, that organisational identity is affected by the opinion of others.

\section{Trust}

Schweizer and Wijnberg (1999) point out that the concept of trust and reputation are clearly related. The relationship, however, is not clear, as there is no precise or clear definition for either of them. The concept of trust is defined in the marketing literature as the perceived trustworthiness and credibility of target (Doney and Cannon, 1997). The concept of corporate reputation includes four main components that are: credibility, trustworthiness, reliability and responsibility (Fombrun, 1996). Based on these four components Fombrun and Van Riel (1997, p. 10) point out that reputation is a subjective collective assessment of an organisation's trustworthiness and reliability based on past performance. Furthermore, reputation has been described as the trustworthiness or the extent of confidence in the source actually carrying out its intentions (Herbig and Milewicz, 1995). Swift (2001) argues that corporate reputation building is about strategically seeking to establish trust in stakeholder relationships in order to negate formal accountability requirements.

In other studies, it has been mentioned that the development of an exceptional reputation is seen as essential for the attribution of credibility or trustworthiness to a firm (Doney and Cannon, 1997). This concept is best illustrated by Caruana (1997) who states that firms have an "array of reputations, and each public considers a different set of attributes. Moreover, even if the same attribute is considered by different publics, it may be given a different weighting". For example Fombrun (1996) states that financial organisations and investors would focus upon the firm's financial performance as an indicator towards good or bad reputation. On the other hand, customers will generally focus on the delivery and the quality of their product or services as an indicator of a good or bad reputation (Yoon et al., 1993). The fact is that firms who are known as having a well managed corporate reputation will influence the consumer's attitude (Fombrun, 1996). Changes in consumer behaviour during the last decade imply that trust and communication are the main factors for building exceptional corporate reputation. Consumers would like to see their favourite firm being moral, paying attention to the environment, and not appearing to be an overly aggressive competitor. For the firms it is very important to communicate with their internal and external environment and present themselves in a way to earn trust. They must take into account that it is possible to satisfy some or most of the consumers all the time but it is nearly impossible to satisfy all the consumers all the time due to cultural differences and different principles.

As discussed, two determinants of corporate reputation are communications, and trust. The influence upon the customer exerted by those two determinants are in turn affected by a series of factors including, but not necessarily limited to: internal/external environment; social and cultural factors; improvement and change in a firm's identity/image; global market activities; product policy; media activities; regulations; and stakeholders perceptions. Figure 2 shows how different factors interact to create a corporate reputation for a firm.

\section{Corporate global branding and the EMNC}

A brand can be defined as "a cluster of functional and emotional values which promises stakeholders a particular experience" (de Chernatony, 2002, p. 4). Brands "act as a 
Figure 2 Corporate reputation communication/trust model

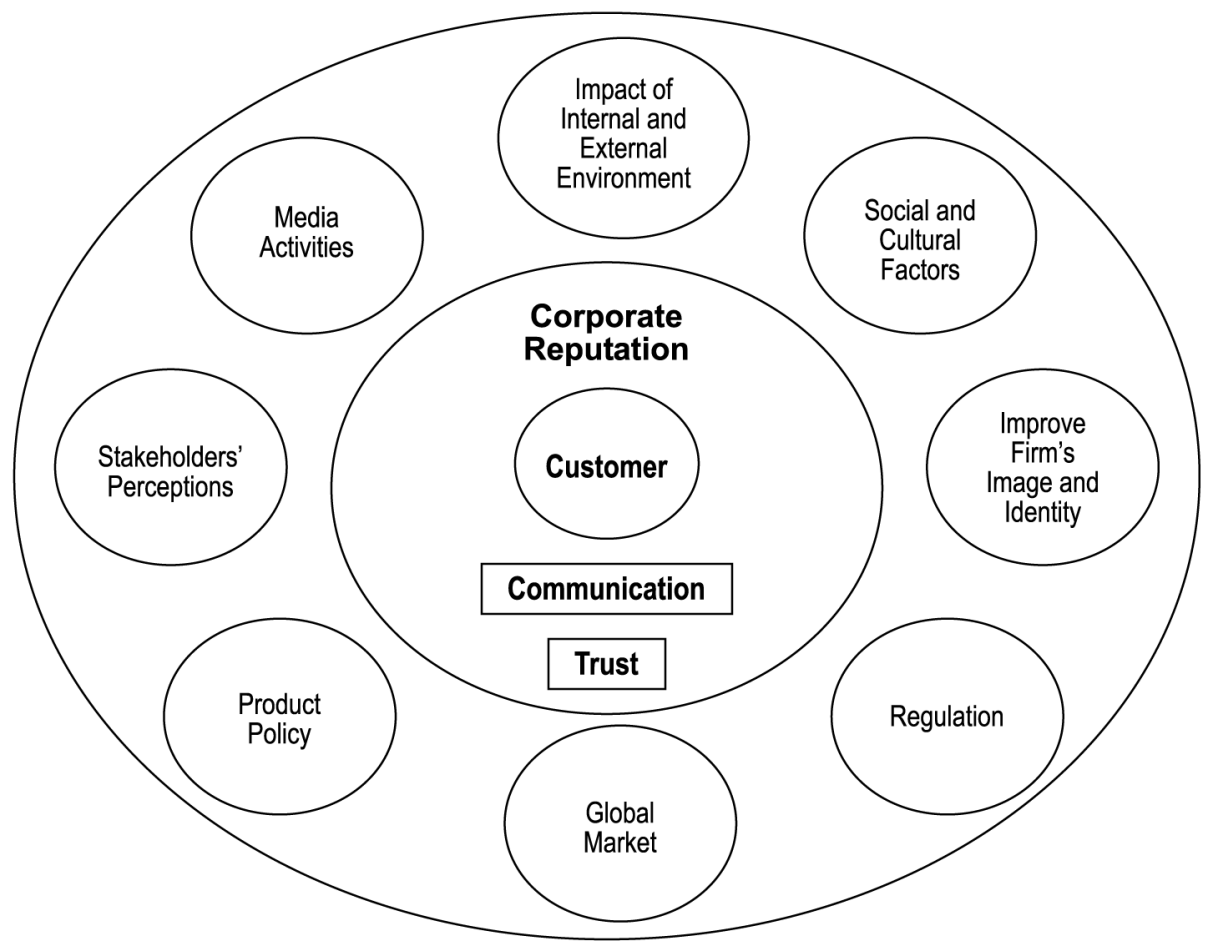

kind of flag, waving to consumers creating awareness of the product and differentiating it from other competitors" (Ellwood, 2000, p. 11).

Today's post-global brand needs to exhibit selective globalisation: a global brand which is also local (Kaprefer, 2005). According to Paba (1986) household appliances are experience goods, whereby reputation is important. Brand loyalty is a significant competitive factor, acting as an information-based barrier to entry, reducing the amplitude of production in the short-run, and allowing firms to experiment.

Globalisation is being driven not just by the giant incumbent firms (Nolan et al., 2002) but also by emerging firms internationalising from the periphery which capture competitive space from incumbents because of their ability to exploit the linkages available through globalisation and developing a culture of continual cross-border learning and value-addition (Bartlett and Ghoshal, 2000; Bonaglia and Goldstein, 2007)

\section{Haier: a case study of an EMNC}

The purpose of this study was to analyse consumers' attitudes and feelings for the Haier logo introduced to the US market (Figure 3) to determine if it was successful in representing the corporation in the USA.

Haier Group is the largest "white goods" manufacturer in China, and the fourth largest in the world. In 2006, Haier overtook Whirlpool as the world's largest refrigerator brand. It has 240 subsidiary companies and 30 design centres, plants and trade companies, and more than 50,000 employees throughout the world, with manufacturing locations in Europe, China, America, Middle East, Spain, and New Zealand. Their full product line includes products such as
Figure 3 Early Haier logo

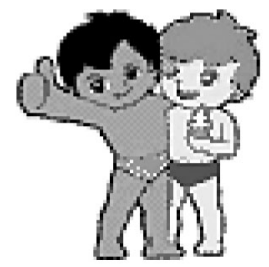

Source: www.haier.com (2003)

refrigerators, freezers, wine cellars, air conditioners, beer dispensers, dishwashers, fans, water dispensers, small appliances and other electronic products. Global revenue was RMB 107.5 billion (www.haier.com/about). Haier is classified as a Global Aspirant (Bonaglia and Goldstein, 2007) in a global white goods market where no participant has greater than 10 per cent market share. Haier was able to evolve from the production of basic goods, to more advanced goods dependent upon their new skills of design, branding and marketing. They are an example of an Emerging MNC (EMNC) - a "second wave" of MNCs from emerging economies. They "... grow large as they internationalise; conversely they internationalise in order to grow large". This shift to an original brand manufacturer (OBM) is the most difficult phase for any latecomer or newcomer MNC (Bonaglia et al., 2006).

The American division of the Haier Group (Haier America) was founded in 1999, with headquarters in New York City and production facilities in South Carolina. "We were the first Chinese company to open a factory in the US," said Shariff Kan, executive vice president of marketing for Haier America. 
"We created jobs here" (www.news.com, p. 2). Latecomer EMNCs like Haier do not have ownership/location/ internalisation (OLI) advantages, and they have to internationalise in order to grow (Bonaglia et al., 2006). Haier has given various reasons for the Camden factory such as being able to respond quickly to orders from retailers while maintaining a low inventory, and cutting transportation costs from China but arguably the main one is the strategic desire to establish the perception of Haier as an "American company", and nationalist pride (Zhao, 2003).

Haier products are currently available through a US distribution channel which includes retail chains such as Wal-Mart, Lowe's, Best Buy, Home Depot, Office Depot, Target, Fortunoff, Menards, Bed Bath and Beyond, P.C. Richards, BJ's, Fry's, ABC, and BrandsMart. Indeed, Haier products received some of the highest quality ratings from Wal-Mart buyers.

\section{Haier brand}

In 1997 the state economic commission in Beijing had designated Haier one of six companies likely to become China's first global brands (Paine and Crawford, 2007). By 2005 Haier was increasing its efforts to build a globally recognised brand, in part due to intense competition and price wars in the domestic (China) market (Palepu et al., 2005). That year it launched the global brand building stage to symbolise the commencement of its fourth development period. Evidence of its success include ranking first in the "Top Ten Chinese Brands in the Consumer Electronics Industry" at the 2007 international Consumer Electronics Show; and being ranked as the most valuable Chinese brand by Financial Times in 2005 (www.haier.com). By 2006 the Haier brand was worth RMB74.9 billion. It is widely predicted that more corporations (such as Haier) will become household brand names (Madden, 2003).

In China, Haier's success in building a national brand was accomplished by segmenting the market, and designing and supplying different products for each segment, to build up Haier brand reputation (Fisher, 2000). Haier has chosen sports as one focus of its global branding effort (Bonaglia et al., 2006), in part by entering into a partnership with the US National Basketball Association, sponsoring soccer teams in Europe, and becoming the official sponsor of the 2008 Beijing Olympic Games for white goods home appliances (www.haier.com). Such partnerships with sports governing bodies confers upon them "image transfer" and other benefits of association (Chadwick and Thwaites, 2005).

Asian CEOs can make a significant contribution by becoming "brand ambassadors" for their companies. Notably, Zhang Ruimin often appears in the international media, which Roll (2006) feels contributes tremendously to the growth and recognition of the Haier brand worldwide. Zhang believes that with increasing globalisation, there will be only two types of firms in every industry in the future: enterprises with global brands, and those working for them. In a recent interview Zhang commented:

The cultural gap or the communication problem is actually the greatest challenge for Haier when it expands overseas. Although we have localised our management team, we feel that cultural differences still make a big difference. For example, when we aimed to be one of the top 10 retailers in the US, our American managers thought it would be impossible to get there in such a short time. However, we managed to find a very good approach and worked only in niche markets with niche products. For instance, we introduced one product tailored for students and another appliance for the use in the living room. These niche products have won the recognition of consumers, and our reputation has been growing (www.chinadaily.com).

The global branding strategy of Haier positions it as a local brand within each market around the world, married with enhanced product competitiveness and strong corporate operations. Zhang felt that Haier had to make Americans feel that Haier is a localised US brand instead of as an imported Chinese brand (Kerin and Peterson, 2007). "We have to march into the global market, otherwise we will never become powerful. We need to do it in three steps - go out, go inside, and then go up in reputation. Zhang insisted that, no matter how much it cost, making appliances in America was the only way for his company to shed its cheap 'made in China' image. Haier has also made a point of competing not simply on the basis of cost, or even quality, but also on pursuing genuine product innovations - the surest route to producing a brand" (www.haier.com/abouthaier/ corporateprofile). In reality, when Haier Group was forming in 1984/1985 they created a joint-venture with the German appliance company Liebherr Group, and initial products were branded "Qindao-Liebherr", believing the German name in the brand name helped boost the image. By 1992 the name changed to "Haier", which is a variation of the word "Liebherr", both in spelling and pronunciation. In Chinese, Haier pronunciation is also a play on the two boys Haier logo, since in Chinese the word "child" is pronounced "hai er" (Yi and Ye, 2003).

Despite a common belief that it takes years for an Asian company to understand western markets, Haier has already achieved a few small successes in reaching middle-class and upper middle-class Americans. After margins began to erode in the mini-fridge market in the early 2000s, executives huddled and came up with the household wine cellar, a new product category, which essentially is a modified mini at a higher price. Haier America President Michael Jamal echos Ruimin's sentiment, stating that word-of-mouth is the best way to promote Haier (Yi and Ye, 2003). In 2002 Jamal noted that "... we promote Haier as a global brand - not Chinese or American..." This "Two Brothers" logo (Figure 3) shows two children: one holding an ice cream cone and the other giving a "thumbs up." In fact, the "Haier twins" logo depicts the toddler on the left with black hair and black eyes representing China, while the other has blond hair and blue eyes and represents the West, according to David Parks, COO of Haier America Refrigerators Co. Ltd, Camden, South Carolina. When the new factory was under construction in Camden, SC, the logo was described by the Atlanta JournalConstitution as:

Two boys in swimsuits, one with black hair and black eyes, the other with blond hair and blue eyes,... The Asian kid wraps his arm around his Caucasian buddy, who holds an ice cream cone. Some thought the new factory would make ice cream, others presumed it was a diaper manufacturer (Chapman, 2004).

\section{Haier logo survey case study}

- Objective 1: Determine how respondents perceive the Haier logo.

- Objective 2: Determine the importance of a product's logo. 


\section{Research methodology}

In the fall of 2004 students from Stevenson University randomly selected people over the age of 18 in the Baltimore, MD metropolitan area, and generated 200 completed questionnaires (two sets of 100). The respondents were given a series of open- and close-ended questions, along with a colour picture of the logo (Figure 3 ).

\section{Findings}

Objective 1: determine how respondents perceive the Haier logo

In general nearly half of the respondents were neutral about the logo, 38 per cent of respondents viewed the logo as positive, while 18 per cent considered it negative. However 71 per cent of the positive respondents indicated they thought it was for a company offering children's products, while only 8 per cent thought it was for appliances. Descriptions included "happy", "excited", "kids", and "cute". Comments included: "thumbs up ...... smiles are positive" and "it has nothing to do with appliances". When asked if they would consider buying a product from a company with this logo on it, given a list of choices, respondents indicated they would buy the following products:

- ice cream (37 per cent);

- children's clothing (33.6 per cent);

- televisions (7.5 per cent);

- shoes (6.2 per cent);

- cleaning supplies (4.8 per cent);

- washing machines (1.4 per cent); and

- microwaves (0.7 per cent).

No one would consider purchasing a refrigerator with this logo on it. When specifically asked about this new logo related to home appliances, 57 per cent felt it was negative, while only 41 per cent indicated it was positive.

When asked to rank manufacturers of refrigerators, Whirlpool scored highest in brand reputation (41 per cent), followed by GE and Maytag (tied at 27 per cent), and Neptune (5 per cent). Haier scored the lowest. Indeed, when asked the last brand of appliance most recently bought, 31 per cent stated Whirlpool, followed by GE (20 per cent), and Maytag/Kenmore (tied at 16 per cent).

Respondents described the boy on the left as Hispanic (52 per cent) Japanese/Asian (18 per cent), or Chinese (10 per cent). Fully 88 per cent felt the boy one the right was Caucasian. A total of 61 per cent indicated that both children in the logo were boys, while 39 per cent thought they were boy/girl. The one word most often associated with this new Haier Logo was "child-like" (40 per cent), "friendship" (24 per cent), "fun" (20 per cent), "diversity" (5 per cent), "dependable" ( 5 per cent), and "quality" (4 per cent).

\section{Objective 2: determine the importance of a product's logo}

Respondents indicated that quality ( 70 per cent) at an affordable price ( 32 per cent) had the greatest influence on their purchase decisions, followed by the brand ( 14 per cent). Additionally, 61 per cent indicated that a familiar logo created the expectation of higher quality.

When asked to agree or disagree with the statement "a product's logo helps me to recognise what brand the product is before I buy it", 65.6 per cent indicated they agreed/
Volume $18 \cdot$ Number $3 \cdot 2009 \cdot 177-187$

strongly agreed, 22.6 per cent were neutral, while 11.8 per cent disagreed/strongly disagreed. But only 17 per cent of the respondents stated that a product's logo would have an effect on how much they would be willing to pay for the product, with 47 per cent indicating it would have no effect and 36 per cent remaining neutral.

In this case study involving Haier, in terms of a logo as a symbol representing corporate reputation, half of the respondents were neutral overall regarding the logo. However if the logo was assigned to products for children, as opposed to their actual product line of white goods, then nearly three-quarters felt positive about the logo/brand/ company reputation. Responses related to quality, price, purchase intentions, and other factors relate to the importance of corporate reputation expressed earlier (Dowling, 1994; Greyser, 1995; Klein and Leffler, 1981; Hebson, 1989; Connor et al., 1997).

This study reveals that in 2003 Haier was deficient in brand recognition in the US market, and would appear to lack the previously referenced exceptional reputation (Howard, 1998). Haier's logo may in fact negatively impact the company, by devaluing an important asset. As Black and Carnes (2000), and Howard (1998) point out, corporate reputation is very fragile and must be constantly maintained. The findings call into question the success of Haier branding to enhance corporate reputation, image, trust, and credibility as they entered the US market (note: In 2004 Haier did change their logo (Figure $4 \mathrm{a}$ ) to just the name (Figure $4 \mathrm{~b}$ ), to better fit the local market).

\section{Future research}

One area of study could include corporate reputation in relation to competitors and competitive advantage. Future research might have to consider the impact of the generic strategy upon the corporate reputation. Researchers could study the relationship between corporate reputation and the degree of involvement in the overseas market. The question will be set to search for the impact of entry mode (export, licensing, franchising, joint venture, wholly owned subsidiary) upon international corporate reputation. Recall that there is limited research done in individual entry modes such as joint ventures. Researchers can investigate the relationship between corporate reputation and entry strategy in terms of degree of standardisation. The question will be set to search for the impact of corporate reputation upon the decision of standardised product. In other words, to what extent do firms standardise their product, taking into account their corporate reputation. And finally, a comparison of the two logos used in the US market can be analysed.

\section{Conclusion}

This paper has attempted to argue a case for the active management of corporate reputation by specifying its relationship with other elements of the firm. A review of corporate personality, corporate identity, and corporate image was undertaken. The paper also explored the development of corporate reputation and for its management, in relation to communication and trust. The paper identified that communication and trust are significant elements for managing the firm's corporate reputation especially in relation to their stakeholders. A customer-centric strategy 
Figure 4 Haier logo

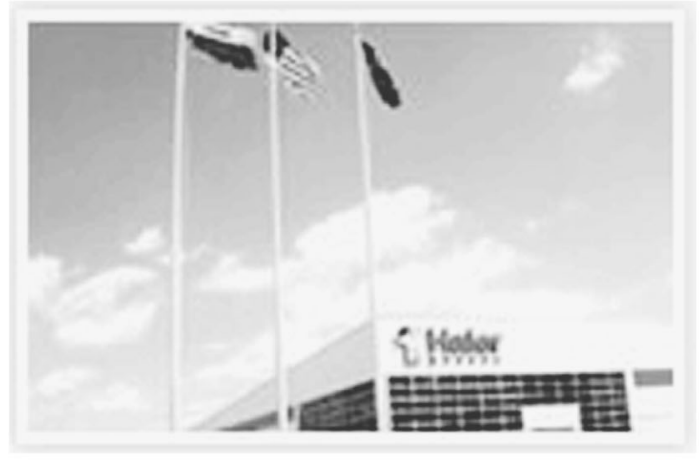

(a) Initial logo

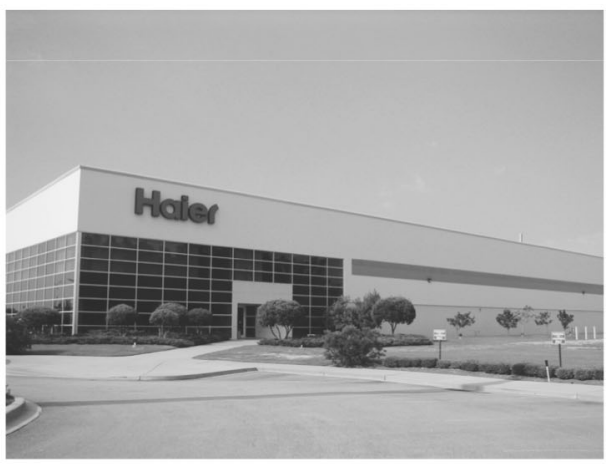

(b) Current logo

Source: www.haier.com

framework was presented, acknowledging the influences that enhance or protect corporate reputation. Finally, a case study involving a corporate logo introduced to a new market by an EMNC was presented, illustrating that past achievements of the firm, involving trust and credibility, need to be managed and communicated to manage corporate reputation.

\section{Managerial implications}

The resource-based view of strategy has argued that sustainable competitive advantage is created primarily from intangible capabilities, notably innovation, organisational architecture, strategic assets, and reputation; with reputation playing a central role (Kay, 1995). Healthly reputation may act as a risk suppressor (Fombrun and Rindova, 1998). Communication (internal and external) and trust are influenced by many controllable and uncontrollable factors, and are determinants of corporate reputation. Managers should be cognisant of their total environment, the pressures of such internal factors on communication and trust; and hence reputation, as a means to suppress risk during the consumer buying process. Fombrun (1996) illustrates that managers should pay increased attention to building and sustaining their reputation, in part by shaping a unique identity, and projecting a coherent and consistent set of images to the public. A company logo is an important visual point associated with corporate reputation. The case discussed here revealed that in this situation, the introduction of their logo into a new market (for example Figure 4a) may have impacted the perception of communication and trust in the public eye. Perhaps tellingly, while an emerging multinational corporation (EMNC) may succeed in a tangible "product" capacity, today's management of intangible competitive advantage involving reputation should be a key executive focus.

\section{References}

Abratt, R. (1989), "A new approach to the corporate image management process", Fournal of Marketing Management, Vol. 5 No. 1, pp. 63-76.

Albert, G. and Whetten, D.A. (1985), "Organisational identity", in Cummings, L.L. (Ed.), Research in Organisational Behaviour, Vol. 7, pp. 263-95.
Source: Author visit

Argenti, P. and Druckenmiller, B. (2004), "Reputation and the corporate brand", Corporate Reputation Review, Vol. 6 No. 4, pp. 368-74.

Balmer, J.M.T. (1995), "Corporate identity: the power and the paradox", Design Management fournal, Winter, pp. 39-44.

Balmer, J.M.T. (1998), "Corporate identity and the advent of corporate marketing", Fournal of Marketing Management, Vol. 14 No. 8, pp. 963-96.

Balmer, J.M.T. and Stotvig, S. (1997), "Corporate identity and private banking; a review and case study", International Fournal of Bank Marketing, Vol. 15 No. 5, pp. 169-84.

Bartlett, C.A. and Ghoshal, S. (2000), "Going global: lessons from late movers", Harvard Business Review, Vol. 78, pp. 133-42.

Beatty, R. and Ritter, J. (1986), "Investment banking, reputation, and the underpricing of initial public offerings", Fournal of Financial Economics, Vol. 15 Nos 1/2, pp. 213-32.

Black, E.L. and Carnes, T.A. (2000), "The market valuation of corporate reputation", Corporate Reputation Review, Vol. 3 No. 1, pp. 31-42.

Bonaglia, F. and Goldstein, A. (2007), "Strengthening productive capacities in emerging economies through internationalization: evidence from the appliance industry", working paper no. 262, OECD Development Centre, Paris, July.

Bonaglia, F., Goldstein, A. and Mathews, J. (2006), "Accelerated internationalisation by emerging multinationals: the case of white goods sector", MPRA Paper No. 1485, MPRA, Munich.

Bromley, D. (2001), "Relationships between personal and corporate reputation", European fournal of Marketing, Vol. 35 No. 3, pp. 316-34

Brown, A. (1995), Organisational Culture, Pitman Publishing, London.

Buchanan, D. and Badham, R. (2001), "Power, politics and organizational change: winning the turf game", fournal of Management Development, Vol. 20 No. 8, pp. 742-3.

Caruana, A. (1997), "Corporate reputation: concept and measurement", Fournal of Product \& Brand Management, Vol. 6 No. 2, pp. 109-18. 
Global brand market-entry strategy to manage corporate reputation

Maktoba Omar, Robert L. Williams $\mathcal{F r}$ and David Lingelbach

Caruana, A. and Chircop, S. (2000), "Measuring corporate reputation: a case example", Corporate Reputation Review, Vol. 3 No. 1, pp. 43-57.

Chadwick, S. and Thwaites, D. (2005), "Managing sport sponsorship programmes: lessons from a critical assessment of English soccer", fournal of Advertising Research, Vol. 45, pp. 328-38.

Chapman, D. (2004), "China set to invest in US manufacturing sites", Atlanta fournal-Constitution, September.

Christensen, T.L. and Askegaard, S. (2001), "Corporate identity and corporate image revisited: a semiotic perspective", European fournal of Marketing, Vol. 35 No. 3, pp. 292-315.

Connor, R., Connor, D. and Davidson, J. (1997), Marketing Your Consulting and Professional Services, John Wiley \& Sons, New York, NY.

Crosby, L., Evans, K. and Cowles, D. (1990), "Relationship quality in services selling: an interpersonal influence perspective", Fournal of Marketing, Vol. 54, pp. 68-81.

de Chernatony, L. (2002), "Would a brand smell any sweeter by a corporate name?", Corporate Reputation Review, Vol. 5 Nos 2/3, pp. 114-32.

Dollinger, M., Golden, P. and Saxton, T. (1997), "The effect of reputation on the decision to joint venture", Strategic Management fournal, Vol. 18 No. 2, pp. 127-40.

Doney, P.M. and Cannon, J.P. (1997), "An examination of the nature of trust in buyer-seller relationships", fournal of Marketing, Vol. 16, pp. 35-51.

Dowling, G.R. (1994), Corporate Reputation, Longman Publishing, New York, NY, pp. 12-20.

Ellwood, I. (2000), The Essential Brand Book, Kogan Page, London, p. 11.

Ewing, M., Caruana, A. and Loy, E.R. (1999), "Corporate reputation and perceived risk in professional engineering services", Corporate Communication: An International fournal, Vol. 4 No. 3, pp. 121-8.

Fill, C. (1999), Marketing Communications, Context, Contents and Strategies, Prentice-Hall, Hemel Hempstead.

Fisher, W. (2000), Building Market Chains at Haier, International Institute for Management Development (IMD), Lausanne.

Fombrun, C.J. (1996), Reputation: Realising Value from the Corporate Image, Harvard Business School Press, Boston, MA.

Fombrun, C.J. (1998), "Indices of corporate reputation: an analysis of media rankings and social monitors ratings", Corporate Reputation Review, Vol. 1 No. 4, pp. 327-40.

Fombrun, C.J. and Gardberg, N. (2000), "Who's tops corporate reputation?", Corporate Reputation Review, Vol. 3 No. 1, pp. 13-17.

Fombrun, C.J. and Rindova, V. (1998), "Reputation management in Global 1000 firms: a benchmarking study", Corporate Reputation Review, Vol. 1 No. 3, pp. 205-12.

Fombrun, C.J. and Shanley, M. (1990), "What's in a name? Reputation building and corporate strategy", Academy of Management fournal, Vol. 33, pp. 210-50.

Fombrun, C.J. and Van Riel, C.B.M. (1997), "The reputation landscape", Corporate Reputation Review, Vol. 1 No. 2, pp. 5-13.

Gotsi, M. and Wilson, A.M. (2001), "Corporate reputation: seeking a definition", Corporate Communications: An International fournal, Vol. 6 No. 1, pp. 24-30.
Greenwald, B. and Kahn, J. (2005), Competition Demystified: A Radically Simplified Approach to Business Strategy, Portfolio, New York, NY.

Greyser, S.A. (1995), "Corporate reputation: aid to growth and shield", Inside PR and Reputation Management, Vol. 1, January/February, pp. 5-6.

Hannebohn, O. and Blöcker, S. (1983), "Corporate communication", Werbeforum, May.

Hebson, R. (1989), Become a Successful Consultant, Foulsham, Slough.

Herbig, P. and Milewicz, J. (1995), "To be or not to be, credible that is? A model of reputation and credibility among competing firms", Marketing Intelligence E Planning, Vol. 13 No. 6, pp. 20-38.

Howard, S. (1998), Corporate Image Management, Butterworth-Heinemann, Singapore, pp. 41-53.

Ind, N. (1998), "The company and the product: the relevance of corporate associations", Corporate Reputation Review, Vol. 2 No. 1, pp. 88-93.

Kaprefer, J.-N. (2005), “The post-global brand”, The fournal of Brand Management, Vol. 12 No. 5, pp. 319-24.

Kay, J. (1995), Foudations of Corporate Success, Oxford University Press, Oxford.

Kerin, R. and Peterson, R. (2007), Strategic Marketing Problems: Cases and Comments, Pearson Prentice-Hall, Upper Saddle River, NJ, pp. 219-36.

Klein, B. and Leffler, K. (1981), "The role of marketing forces in assuring contractual performances", fournal of Political Economy, Vol. 89, pp. 615-41.

Levitt, T. (1965), Industrial Purchasing Behavior: A Study of Communication Effects, Harvard Business School, Boston, MA.

Lewis, S. (2001), "Measuring corporate reputation", Corporate Communications: An International fournal, Vol. 6 No. 1, pp. 31-5.

Madden, N. (2003), "China's power brands eye global expansion", Advertising Age, Vol. 74 No. 2, p. 12.

Markwick, N. and Fill, C. (1997), "Towards a framework for managing corporate identity", European Fournal of Marketing, Vol. 31 Nos 5/6, pp. 396-410.

Martineau, P. (1958), "The personality of the retail store", Harvard Business Review, January-February, pp. 47-55.

Milgrom, P. and Roberts, J. (1986), "Price and advertising signals of product quality", International Library of Critical Writing in Economics, Vol. 136, pp. 364-89.

Nolan, P., Sutherland, D. and Zhang, J. (2002), "The challenge of the global business revolution", Contributions to Political Economy, Vol. 21, pp. 91-110.

Olins, W. (1989), Corporate Identity: Making Business Strategy Visible through Design, Thames \& Hudson, London.

Paba, S. (1986), "Brand-naming as an entry strategy in the white goods industry", Cambridge Fournal of Economics, Vol. 10, pp. 305-18.

Paine, L.S. and Crawford, R. (2007), Haier Hefei Electronics Co. (A), HBS No. 398-101, Harvard Business School, Boston, MA.

Palepu, K., Khanna, T. and Vargas, I. (2005), "Haier: taking a Chinese company global", 10/17/2005, case 9-706-401, Harvard Business School, Boston, MA.

Rindova, V.P. (1997), "The image cascade and the formation of corporate reputations", Corporate Reputation Review, Vol. 1 Nos 1/2, pp. 189-94.

Roll, M. (2006), Asian Brand Strategy: How Asia Builds Strong Brands, Palgrave Macmillan, New York, NY. 
Schweizer, T. and Wijnberg, M.N. (1999), "Transferring reputation to the corporation in different cultures: individuals, collectives, system and the strategic management of corporate reputation", Corporate Reputation Review, Vol. 2 No. 3, pp. 249-66.

Spence, A.M. (1974), Market Signaling: Informational Transfer in Hiring and Related Screening Procedures, Harvard University Press, Cambridge, MA.

Stigler, G.J. (1962), "Information in the labor market", Fournal of Political Economy, Vol. 69, pp. 49-73.

Swift, T. (2001), "Trust, reputation and corporate accountability to stakeholders", Business Ethics: A European Review, Vol. 10 No. 1, pp. 16-26.

Van Riel, C. (1995), Principles of Corporate Communication, Prentice-Hall, Hemel Hempstead.

Van Riel, C. (1997), "Corporate identity: the concept, its measurement and management", European fournal of Marketing, Vol. 31 Nos 5/6, pp. 340-55.

Weigelt, K. and Camerer, C. (1988), "Reputation and corporate strategy: a review of recent theory and applications", Strategic Management fournal, Vol. 9 No. 5, pp. 443-54.

Yi, J. and Ye, S. (2003), The Haier Way, Homa and Sekey Books, Dumont, NJ.

Yoon, E., Guffey, H.J. and Kijewski, V. (1993), "The effects of information and company reputations on intentions to buy a business service", Fournal of Business Research, Vol. 27, pp. 216-28.

Zhao, Y. (2003), "When jobs move overseas (to South Carolina)", New York Times, October 26.

\section{Further reading}

Brassington, F. and Pettitt, S. (1997), Principles of Marketing, Pitman Publishing, London, p. 275.

Hunger, J.D. (2003), "US major home appliance industry in 2002: competition becomes global", in Wheelen, T. and Hunger, J. (Eds), Strategic Management and Business Policy, Prentice-Hall, Upper Saddle River, NJ.

Saxton, K. (1998), "Understanding and evaluating reputation", Reputation Management, May/June.

Schwaiger, M. (2004), "Components and parameters of corporate reputation: an empirical study", Achmalenbach Business Review, Vol. 56, pp. 46-69.

\section{About the authors}

Maktoba Omar is a graduate of Leeds University Business School. Currently a Lecturer of International Marketing Strategy at Napier University Business School, Edinburgh, Scotland and member of the research committee. She is also a part time research visitor at Harbin University of Commerce, China. Current research interests focus on globalisation, international strategy and marketing policy. She has published in a number of national and international academic journals as well as presented at conferences and workshops.

Robert L. Williams Jr is currently an Assistant Professor of Marketing in the School of Business and Leadership at Stevenson University. A graduate of The Pennsylvania State University, he previously taught at Susquehanna University and Duquesne University after a $20+$ year practitioner career in various management positions at Fortune 50 company Tyco International, and AMP Inc. $\mathrm{He}$ has published in academic journals as well as presented at conferences and workshops. Current research focuses on Higher Education Institution branding, renaming/ repositioning, customer co-creation, and competitive advantage. Robert L. Williams $\mathrm{Jr}$ is the corresponding author and can be contacted at: rlwilliamsjr@stevenson.edu

David Lingelbach is an Assistant Professor of Business at Stevenson University and a Professorial Lecturer at Johns Hopkins School of Advanced International Studies. His research interests are focused on entrepreneurship in developing countries, with a special interest in entrepreneurial finance.

\section{Executive summary and implications for managers and executives}

This summary has been provided to allow managers and executives a rapid appreciation of the content of the article. Those with a particular interest in the topic covered may then read the article in toto to take advantage of the more comprehensive description of the research undertaken and its results to get the full benefit of the material present.

In recent times, corporate reputation has become recognised as significantly influencing an organisation's chances of securing and sustaining competitive advantage. Reputation is equally important to customers too. It serves as a guarantee of quality and also reduces perceptions of risk. So much so, many consumers are extremely reluctant to get involved with new companies with no established record.

\section{How corporate reputation is formed}

Studies have also indicated that reputation helps a company forge closer relations with its customers. Companies of higher repute are more adept at projecting their core mission and identity and also tend to keep interested parties fully informed about a wider range of issues. A good reputation also has the capacity to:

- differentiate an organisation from its competitors;

- entice better employees and investors to the firm;

- increase consumer perceptions that the company offers high quality products; and

- generate positive word-of-mouth recommendations.

The importance of enhancing or rebuilding corporate reputation has also not gone unnoticed. To achieve this goal, organisations need to: create a distinctive identity that is reiterated through clear, consistent messages, offer quality products and services supported by effective management practices, be sensitive to environmental concerns, increase community involvement, and practice good PR. However, variations may exist within different nations, industries and strategic contexts.

Omar et al. note that reputation is also closely related to corporate personality, corporate identity and corporate image. Confusion exists about the nature of the relationship between these concepts that are variously defined as identical, interchangeable or discrete.

Many theorists believe that corporate personality and corporate identity are closely related. Identity reflects the firm's personality, which has been described as the "initial building block" that can often be shaped by the company founder, core values and beliefs or the culture of the 
organisation. Another suggestion is that the firm's overall strategic purpose can also determine corporate personality.

Identity is therefore seen as important as it must properly convey the personality of the organisation. It is essentially formed through a "combination of visual and non-visual means" chosen by the company to represent itself to specific groups. These cues help outsiders to differentiate one organisation from another with similar product offerings. Through prompts that can include corporate logos and letterheads, a firm is to some extent able to control how different stakeholders will perceive it. Consistency of message is again vitally important in order to ensure that the right identity is conveyed.

Consensus exists that corporate image refers to the external perception of the organisation. This perception is determined by audience interpretation of the various cues presented by the firm. Different researchers have pointed out that companies must focus on corporate identity in order to influence corporate image as they cannot manage the latter concept directly. Image has also been labelled as a "direct projection of the corporate identity" but this projection may vary among different stakeholder groups.

In the current study, the authors discuss ways to improve or protect corporate reputation and regard effective communication and trust building as vital elements of any strategy. Both internal and external communication is important and companies should be aware of this fact. Interacting with customers through various communication channels improves understanding of what matters to them.

Trustworthiness is regarded as a key to corporate reputation. The measure of trust in shaped by "subjective collective assessment" that results from an organisation's past record. Various attributes are associated with trust and their importance might differ depending on the stakeholder group involved. For instance, investors are likely to base their assessment of trust on a firm's financial performance, while a customer will trust reliable companies that deliver quality goods or services. The influence of communication and trust on reputation is in part shaped by other aspects that might include product policy, global market activities, regulations and social and cultural factors.

\section{Study and recommendations}

Omar et al. illustrate some of the points made in a case study of the Haier Group, one of the world's largest manufacturers of white goods. The main purpose of the study is to evaluate consumer attitudes and feelings for the brand logo Haier introduced to the US market. Haier became the first Chinese company to open a factory in the US when founding the American division of the firm in 1999.

In 2005, the organisation began increasing its efforts to "build a globally recognised brand" and this led to the creation of partnerships with sports governing bodies. Haier could therefore benefit from the transfer of images and other associations. Setting up the American division also helped to position Haier as a local company rather than a cheap imported brand from China. The organisation had used a similar strategy during its formation in the 1980s, when Haier joined forced with the Liebherr Group and exploited the German name of its partner to boost its own image.

Since the early 2000s, Haier has promoted itself as a global brand and its logo is considered a key aspect of that projection. The "Two Brothers" logo features two children that are commonly perceived as signifying China and the West respectively.

Part of the case study involves asking respondents how they perceive the Haier logo and how important they consider a product logo to be. The authors obtained 200 completed questionnaires from people aged over 18 in Baltimore, USA.

Findings revealed that the majority of respondents:

- felt the logo belonged to a firm offering products to children and only 8 percent made the connection to household appliances;

- considered the logo negative when informed of its true nature;

- ranked Haier lowest on a list of refrigerator manufacturers;

- associated a familiar logo with quality expectations, however, the Haier logo signified quality for only 4 percent of those surveyed;

- said that product logo was important for brand recognition; and

- would feel positive about brand reputation if this logo was used in connection with children's products.

Omar et al. believe these findings indicate that recognition of the Haier brand in the US was limited when the study was carried out in 2003. They note the fragile nature of corporate reputation and the likely negative impact on the brand from a logo that has been subsequently changed.

The authors urge companies to be mindful of their whole environment and of internal factors that impact on communication and trust to help reduce consumer perception of risk during the buying process. They likewise recommend creating a unique identity that is displayed consistently to the public using images that include a relevant brand logo. In the Haier case, it is supposed that the chosen image may have affected public perception of communication and trust, and therefore brand reputation.

Future study may explore the impact of competitors and competitive advantage on corporate reputation. Degree of involvement in a foreign market and the significance of a company's entry mode could also be considered. How much reputation leads to standardised products from the firm is another avenue to investigate.

(A précis of the article "Global brand market-entry strategy to manage corporate reputation”. Supplied by Marketing Consultants for Emerald.)

To purchase reprints of this article please e-mail: reprints@emeraldinsight.com

Or visit our web site for further details: www.emeraldinsight.com/reprints 